\title{
Comparative Study on Performance Measures and Attributes between ISO and Non-ISO Certification Companies
}

\author{
Mohd Zulkifli Mokhtar \\ Faculty of Management and Economics, University of Malaysia \\ Terengganu, Mengabang Telipot, 21030 Kuala Terengganu, Malaysia \\ E-mail: zulkifli@umt.edu.my
}

Associate Professor Mohd Shaladdin Muda (Corresponding author)

Faculty of Management and Economics, University of Malaysia

Terengganu, Mengabang Telipot, 21030 Kuala Terengganu, Malaysia

E-mail: shaladdin@umt.edu.my

Received: September 20, 2011

Accepted: November 21, 2011

Published: February 1, 2012

doi:10.5539/ijbm.v7n3p185

URL: http://dx.doi.org/10.5539/ijbm.v7n3p185

\begin{abstract}
This study surveys a sample of 162 public listed companies on the Kuala Lumpur Stock Exchange. The study utilises eight different measures of company performance, ROA, ROE, WC, ROS, CF, TQ and EVA, and five company's attributes, namely size, growth. capital structure, age and industrial category. The analyses revealed that ISO registered Malaysian companies outperformed their non-ISO registered counterparts during the period of this study. This study finds that ISO 9000 registered companies in Malaysia are better off than non-ISO 9000 registered companies in terms of performance measures ROA, ROS and WC, except for EVA. ISO 9000 registered companies are younger, larger, and have a higher growth and a lower capital structure than non-ISO 9000 registered companies.
\end{abstract}

Keywords: Performance, ISO 9000 Registration, Return on Assets, Working Capital, Economic Value Added

\section{Introduction}

In the era of globalization, as global competition intensifies, Malaysian awareness on the subject of standard setting has been heightened recently due to it's acceptance of the Asian Free Trade Area (AFTA) Agreement in January 2004. AFTA laid out a comprehensive program of regional tariff reduction, to be carried out in phases through to the year 2008. Over the course of the next several years, the program of tariff reductions was broadened and accelerated, and a host of "AFTA Plus" activities was initiated, including efforts to eliminate non-tariff barriers and quantitative restrictions, harmonize customs nomenclature, valuation and procedures, and develop common product certification standards, which could be certified by the International Organization for Standardization (ISO).

The main purpose of this study is to determine and analyse empirically the factors that affect the performance in Malaysian ISO 9000 and non-ISO 9000 companies. In particular, the study analyses corporate performance measures and certain company attributes such as size, capital structure, age, growth, and industrial category. The results of this study will help the corporate managers to concentrate their limited economic resources to ISO 9000 certification. As for investors, they can narrow down their investment portfolio on companies that have ISO 9000 certification which could produce a better return. Also, the findings of the study may be used as guidelines in advancing the relevant recommendations to help decision- and policy-makers engaged in strategy formulation and implementation to improve and enhance the performance of their companies, especially towards "AFTA Plus".

The overall research question addressed by this study can be stated as follows: Do companies with ISO 9000 certification perform better than non-ISO 9000 certification companies? To answer this main research question, seven financial performance measures were used, which include Return on Assets (ROA), Return on Equity 
(ROE), Working Capital (WC), Cash Flow (CF), Return on Sales (ROS), Economic Value Added (EVA) and Tobin's Q (TQ) in order to compare the performance of ISO 9000 and non-ISO 9000 certification companies. Besides that, another five important company attributes were selected which include the size of the company, company's capital structure, the age of the company, the growth of the company and the industry category of the company.

The remainder of the paper is organized as follows. Literature review on ISO 9000 certification, performance measures and other company attributes used is discussed in the following section. Research methodology will be highlighted in section 3 . While the data analysis and findings are offered in section 4 , the summary and conclusions are presented in the final section.

\section{Literature review}

\subsection{Literature review on ISO 9000 and performance measures}

As ISO 9000 certification will be used as one of the company attributes in this study, other studies that utilises ISO 9000 certification to measure performance are Krajewski et al. (2010), Stevenson (2009), Naveh and Marcus (2004), Cebeci and Beskese (2002), Corbett et al. (2002), Aarts and Vos (2001), Haversjo (2000) and Carr et al. (1997). Naveh and Marcus (2004) study on ISO 9000 and performance improvement. Their study draws on four sources to show how ISO 9000 can lead to performance improvement which include a case study of a telecom company and a survey of 1,150 North American Companies. They find that the extent to which ISO 9000 is associated with performance improvement depends on the level of its assimilation, and the degree to which an organization goes beyond the minimal requirements of the standard. However, Cebeci and Beskese (2002) study on the evaluation of quality performance which include ISO 9000 of the companies in Turkey, using questionnaire where it covered approximately 250 companies and produced 91 usable responses with 36 response rate. They found that quality and export sales can drive each other to the higher levels, where a company has higher quality products, it will be much easier to increase the export sales. Besides that, Corbett $e t$ al. (2002) employed an event study methodology on U.S. firms, to test whether ISO 9000 registration leads to productivity improvements, market benefits, and improved financial performance. They tracked the financial performance of all publicly traded ISO 9000 registered firms in several industrial sectors in the USA. They found that firms sought their first ISO 9000 certification did indeed lead to significant abnormal improvements in financial performance, though the extent to which these are driven by productivity or market effects varied across sectors. They also reported that publicly traded firms in three US sectors did experience improvements in Return on Assets and, depending on the industry, also in productivity and sales. Whereas, Haversjo (2000) study on the profitability of ISO 9000 registered Danish companies comparing to the profitability of companies not holding any quality system registration, a group of 644 companies with similar distribution of size not holding a quality system registration was taken. In order to make comparisons between the two populations the median figures of each population is compared for the same fiscal year. He found that, in general, the ISO population companies seem to have a significantly higher rate of return than the control population both before and after registration. Carr et al. (1997) study investigates whether ISO accredited companies differ from non-ISO accredited companies in business strategy and in their implementation of quality management practices and reporting of New Zealand companies. Based on the mail questionnaire sent to a sample of ISO and non-ISO accredited New Zealand manufacturing companies, the results showed a significant different in the business strategy pursued by the two groups, with ISO accredited companies regarding quality as more important than cost efficiencies. However, there was no significant difference in the quality management practices of ISO accredited and non-ISO accredited companies, except in the areas of process improvement and quality measurement. There was also little evidence of differences in performance reporting systems between ISO accredited and non-ISO accredited companies.

\subsection{Measures of financial corporate performance}

Return on Assets (ROA). Return on Assets (ROA) is a useful indicator of how profitable a company is relative to its total assets. It also gives an idea as to how well the company is able to use their assets to generate earnings. Calculated by dividing a company's annual earnings with it's total assets. ROA is displayed as a percentage. Sometimes this is referred to as "return on investment". The ROA figure gives investors an idea as to how effectively the company is converting the money that they have invested into net income. The higher the ROA figure the better it is seen as the company is earning more money on less invested company. Among the researchers that used ROA are, Mokhtar et al. (2005) and Corbett et al. (2002), found that after ISO 9000 certification, companies tended to report abnormal improvements in ROA and more importantly, these improvements were found to be lasting. 
Return on Equity (ROE). Return on Equity (ROE) is a measure of a company's profitability. It is calculated as a ratio of net income over the shareholder's equity. Essentially, ROE reveals how much profit a company generates with the money that the shareholders have invested in it. The ROE is useful for comparing the profitability of a company to that of other firms in the same industry. Return on Equity (ROE) was used because it measures the rewards of ownership and takes alternative financial structures and risk levels into account (Schendel and Patton, 1978). In this way, it offers a measure of both management performance and financial strategy.

Return on Sales (ROS). Return on Sales (ROS) is a widely used ratio that detects operational efficiency. It is calculated as a ratio of net income (before interest and tax) over sales. ROS is a measure that is helpful to management, providing insight into how much profit is being produced per dollar of sales. ROS is also known as a firm's operating profit margin. It is the most commonly used profitability measure (Jacobson and Aaker, 1987; Kay and Davis's, 1990; Naser et al., 2004). Naser et al. (2004) used ROS as one of their company performance measures and they found that ROS determined the performance of Malaysian ISO 9000 registered companies.

Working Capital (WC). Working Capital (WC) ratio is a company's current assets over its current liabilities, which is considered a good measure of both a company's efficiency and its financial health. The higher the ratio, the better the efficiency of the company, that is, the current assets are able to payoff their short-term liabilities. Working capital also gives investors an idea of the company's underlying operational efficiency. Among the researchers that used WC as their performance measures are Kay and Davis (1990); Bhimani (1993); Burton (1994); and Pat (1995). Bhimani (1993), for instance, used WC ratio to investigate twenty-one UK companies in order to provide an overall picture of performance measurement in the UK manufacturing sector. The study highlighted the importance of working capital and lender security as a performance measure.

Cash Flow (CF). Cash Flow (CF) is the amount of cash a company generates and uses during a period, calculated by adding non-cash charges (such as depreciation) to the net income after taxes. Cash flow can be used as an indication of a company's financial strength. Cash flow is crucial to companies and by having ample cash on hand will ensure that creditors, employees and others can be paid on time. Among the researchers that used cash flow, include Perkins and Van Zyl (1994) and Naser et al. (2004).

Economic Value Added (EVA). Economic Value Added (EVA) is a measure of a company's financial performance based on the residual wealth calculated by deducting cost of capital from its operating profit. The formula used for calculating EVA is the net operating profit after taxes less the cost of capital. EVA attempts to capture the true economic profit of a company. EVA is a way of evaluating a company's real profitability and how effectively it is performing. Among the researchers that used EVA as their performance measures include, Perkins and Van Zyl (1994); Pat (1995); Naser et al. (2004); and Mokhtar et al. (2005). Naser et al. (2004) employed EVA as one of their measures of company performance. They found that EVA determined the performance of Malaysian ISO 9000 registered companies.

Tobin's Q (TQ). Tobin's Q (TQ) ratio is devised by James Tobin, who hypothesized that the combined market value of all the companies on the stock market should be about equal to their replacement costs. The TQ ratio is calculated as the market value of a firm's equity plus its debt, divided by the book value of its total assets. For example, a low $\mathrm{Q}$ (between 0 and 1) means that the cost to replace a firm's assets is greater that the value of its stock, which implies that the stock is undervalued. Conversely, a high Q (greater than 1) implies that a firm's stock is relatively more expensive than the replacement cost of its assets, which implies that the stock is overvalued. The TQ ratio is a measure of stock valuation, which is the driving factor behind investment decisions. Among the researchers that used TQ ratio as their performance measures include, Corbett et al, (2002); and King \& Lenox (2002).

\subsection{Other Company attributes}

Company Size. This study used total assets as a basis to determine company's size. Baumol (1956) hypothesized that corporate performance increases with the size of the firm. Gupta (1969) carried out a study on the effect of size, growth and industry on the financial structure of a hundred and seventy-three American manufacturing companies for the year $1961-1962$. He found that activity ratios and leverage ratios were found to decrease with an increase in the size of the firm, but to increase with the growth of the firm. Liquidity ratio rose with an increase in the size of the firm but fell with the growth rates. The larger-sized firms tended to have higher profit margin on sales than the smaller-sized firms. Mokhtar et al. (2006) found that size a factor that determines the performance of Malaysian companies.

Company's Growth. Growth in sales is used as growth rate in this study. Among studies that used company's growth as a proxy for performance measures include Dess and Davies (1986), Lee et al. (1990) and Johnson and 
Soenen (2003). Dess and Davies (1986) carried out a study on the determinants of strategic group membership and organizational performance of U. S. firms. Among the findings, based on sales growth, the overall F-ratio indicated that the groups were significantly different from one another. Johnson and Soenen (2003) carried out a study on the indicators of successful companies using Compustat data for 478 companies covering the period 1982-1998, which investigated factors that discriminate between financially successful and less successful companies. A binary logit model was applied to quantify the relationship between the individual firm characteristics and the probability that a particular measure of success would be greater or lower than the average for all firms considered. The study finds that especially large, profitable firms with efficient working capital management (i.e., relative short cash conversion cycles) and a certain degree of uniqueness (measured by advertising spending relative to sales) outperformed the sample average on the three performance measures.

Company's Capital Structure. This study uses capital structure ratio as the ratio of debt total assets. Capital structure or leverage ratio was used by Mulford (1985) study on the importance of a market value measurement of debt in leverage ratios where he used the book value measures for a sample of 100 firms, which were drawn from the annual COMPUSTAT industrial file for the years 1979 and 1980. He found that financial leverage ratios computed using market-value-based measures of debt consistently exhibited a greater association with market beta than did their book-value-based counterparts. Mokhtar et al. (2006) found that capital structure do determines the performance of Malaysian public listed companies.

Company's Age. Another important variable that will be used in the study is the firm's age since incorporation. Studies that have used firm age as one of their variables include, Khan and Rocha (1982), Kalleberg and Leicht (1991), Brush and Chaganti (1999) and Rupp and Smith (2002).

Industry Category. Industry category or classification is another attributes variable that will be used in this study. The industry category that is being used by this study include industrial product, consumer product, construction, trading and services, plantation and other industries. Among studies that utilises industry category as one of the attributes to measure performance are Bain (1956), Demsetz (1973), Kania and McKean (1978), Porter (1979), Khan and Rocha (1982), Schmalensee (1985), and Hensen and Wernerfelt (1989). Porter (1979) suggested that links exist between a firm's profits and industry structure, and thus that firms in some strategic groups would be more profitable than others. Demsetz (1973) has, for example, found that the profits of smaller firms are not higher in concentrated industries than they are in unconcentrated industries, though the profits of larger firms are. A study by Schmalensee (1985) revealed that differences between industries, as measured by average industry return on assets, account for almost all the explained variance in business unit performance.

\section{Methodology}

The main method of data collection for this study was through the use of secondary data. The first step in the data collection process for the present study was to identify the sampling frame for the companies. The source used to verify ISO 9000 registration was the Standards and Industrial Research Institute of Malaysia (SIRIM). Assessment and certification to ISO 9000 in Malaysia is carried out by SIRIM, as it is the only local ISO 9000 certification body in Malaysia. Companies certified by SIRIM are listed in the SIRIM Directory of Certified Products and Companies; to date, there are over 1500 such companies. The SIRIM database provides a listing of all ISO 9000 registered companies in Malaysia. To control for potential differences between industries, the sample for this study was drawn from this site. The list of potential companies and all associated financial data were acquired from the Bursa Malaysia (previously called Kuala Lumpur Stock Exchange) database, thus ensuring that all the data were comparable. Data for the years 1998-2001 were used in this study. This time frame was chosen in order to exclude the period before 1997, the year of economic crisis in Malaysia.

As at the end of 2002, this study identified a random sample consisted of 162 companies listed on the Bursa Malaysia database, which had a population of 736 companies listed in 1998. The sample collected accounts for 22 per cent of the population. Two samples were extracted from the database; one sample was comprised of 81 ISO 9000 certified companies selected from the SIRIM database, and the second sample consisted of a comparable group of 81 companies that were not registered to ISO 9000. The choice of these companies was based on their listing status. All companies registered on the ISO 9000 and listed on the KLSE formed the primary sample of this study. The non-accredited ISO 9000 companies were chosen randomly from the best performing companies in terms of turnover listed on the KLSE. By the end of 1998, there were 1,707 ISO accredited companies on the Malaysian Standard (SIRIM) database.

\section{Data Analysis}

\subsection{Descriptive Statistics}

Table 1 contains descriptive statistics of the variables used in this study. The table reveals that ROE, it ranges 
between -4.2546 and 1.0504 , with a mean of -0.06011 and a standard deviation of 0.4483519 . The same applies to $\mathrm{CF}$, which show that the standard deviation is more than the mean. This implies that there is a high variations in the companies' mean. Looking at the variable AGE, the number of companies used in the study sample is 162 , and the range of ages is from 4 to 94 years, with a mean of 28.44 and a standard deviation of 17.94. As for SIZE, the range of SIZE scores is between 4,358,075 and 38,670,900,000, with a mean of 1,401,574,715 and a standard deviation of 4,028,687,121. Looking at GROWTH, the range of GROWTH scores is between -0.52 and 11.90 , with a mean of 0.1557 and a standard deviation of 1.1059. As for CAPSTRUC, the range of CAPSTRUC scores is between 0.0803 and 17.4579, with a mean of 1.0327 and a standard deviation of 1.7438 (Pallant, 2001). For the categorical variables, dummy variables were being used.

\subsection{Analysis of T-Test Results on ISO 9000 and non-ISO 9000 registered companies}

To identify variations in the performance and company attributes between ISO 9000 registered and non-registered firms, an independent-samples t-test was performed and the results are reported in Table 2.

Looking at table 2, this study found a significant difference in ROA, ROS, WC and EVA between ISO 9000 registered companies, and non-ISO 9000 registered companies at the 5 percent level. This shows that ISO 9000 registered companies perform better than non-ISO 9000 registered companies in terms of ROA, ROS, WC and EVA.

Referring to the age of the company, this study found that there is a significant difference the age for ISO 9000 registered companies and non-ISO 9000 registered companies, significant at the 5 percent level. This means that younger companies are more likely to have ISO 9000 registration compared to older companies. Looking at the size of the company (based on total assets), this study found that there is a significant difference between the size of the ISO 9000 registered companies and non-ISO 9000 registered companies. This indicates that ISO 9000 registered companies are larger compared to non-ISO 9000 registered companies.

As for the capital structure (based on the ratio of debt to total assets), this study found a significant difference in capital structure between ISO 9000 registered companies and non-ISO 9000 registered companies. This reveals that non-ISO 9000 registered companies are high in their debt to total assets ratio. Looking at the industrial category, this study found that there is a significant difference in the industrial product category, in that more companies under the industrial product category are found to be registered with ISO 9000 compared to non-ISO 9000 registered companies. Also, referring to other industries category, this study found a significant difference in the 'other industries' category, as there were no ISO 9000 registered companies classified under 'other industries' compared to non-ISO 9000 registered companies significant at the 5 percent level.

As well as the above findings, which show significant differences between ISO 9000 registered and non-ISO 9000 registered companies, Table 2 also shows the mean difference in terms of other performance variables and company attributes. Looking at the mean difference in terms of ROE, ISO registered companies show a positive mean of 0.084563 , whereas non-ISO registered companies show a positive mean of 0.035667 , which is much less than that of ISO companies. This shows that ISO companies are performing better than non-ISO companies in terms of ROE. Also, looking at CF, ISO companies show a mean of 85979138, whereas non-ISO companies show a mean of 35828117. This shows that ISO companies are performing better than non-ISO companies in terms of CF. As for the growth of the company, ISO companies show a mean of 0.3059 , whereas non-ISO companies show a mean of 0.0055 . This shows that ISO companies have better growth in sales than non-ISO companies. Referring to the Pearson correlation analysis, it is found that company growth is positively correlated with ISO 9000. This reveals that companies that are registered with ISO 9000 experience a higher growth than companies that are not registered with ISO 9000.

\section{Summary and Conclusions}

This study surveys a sample of 162 public listed companies on the Kuala Lumpur Stock Exchange for the period between 1998 and 2001. The study utilises eight different measures of company performance, ROA, ROE, WC, ROS, CF, TQ and EVA, and five company's attributes, namely size, growth. capital structure, age and industrial category.

The analyses revealed that ISO registered Malaysian companies outperformed their non-ISO registered counterparts during the period of this study. Thus, this study lends support to some of the findings reported in Haversjo (2000), Heras et al. (2002), and Corbett et al. (2002) regarding ISO 9000 registration and its impact on company performance. As a summary of the T-Test results on the corporate performance differences and company attributes between ISO 9000 registered and non-ISO 9000 registered companies, this study finds that there is a significant difference between ISO 9000 registered companies and non-ISO 9000 registered companies 
in terms of ROA, ROS, WC, EVA, age of the company, size of the company, capital structure and industrial product category of industry in which the companies operate. In terms of corporate performance measures ROA, this study shows that ISO 9000 registered companies outperformed non-ISO 9000 registered companies where ISO companies are effectively converting their money that they have invested into net income compared to non-ISO companies. Looking at ROS, ISO companies are producing a higher per dollar of sales compared to non-ISO companies. As for working capital, the finding shows that ISO companies are more efficient in their working capital management where they are able to payoff their short-term liabilities compared to non-ISO companies. The only corporate performance measure in which non-ISO 9000 registered companies outperformed ISO 9000 registered companies was EVA. In terms of age, ISO 9000 registered companies are found to be younger than non-ISO 9000 registered companies. As for size (based on total assets), ISO 9000 registered companies are found to be larger than non-ISO 9000 registered companies. The growth (based on sales growth) of ISO 9000 companies is higher than that of non-ISO 9000 registered companies. In terms of capital structure (ratio of debt to total assets) ISO 9000 registered companies are found to have a lower capital structure than non-ISO 9000 registered companies.

Our results should, however, be treated with a degree of caution since improved financial performance could be attributed to many reasons rather than ISO 9000 certification alone. Nevertheless, our findings and that of similar researchers do support the view that careful design and implementation of consistent and documented quality management systems contributes to superior financial performance. Some cautionary points must be taken into considerations before interpreting particular results. The distribution of sizes of companies within our sample must be borne in mind, and also the high level of homogeneity in the sample. These characteristics of the sample, which add to its interest by making it different from most others used, mean that the results obtained may be strongly sample-specific. The fact that many of the findings are consistent with theory or otherwise plausible gives greater confidence, but should not obscure this possibility.

As an overall conclusion, the T-Tests results indicate that ISO 9000 registered companies in Malaysia are found to be better off than non-ISO 9000 registered companies in terms of performance measures ROA, ROS and WC, except for EVA. ISO 9000 registered companies are younger, larger, and have a higher growth and a lower capital structure than non-ISO 9000 registered companies. The analysis revealed that ISO 9000 registered Malaysian companies outperformed the unregistered ones during the period of study.

\section{References}

Aarts, F. M., \& Vos, E. (2001). The impact of ISO registration on New Zealand firms performance: a financial perspective. The TQM Magazine, 13(3). 180-191. http://dx.doi.org/10.1108/09544780110384871

Bain, J. S. (1956). Barriers to new competition. Harvard University Press, Cambridge, MA.

Baumol, W. J. (1956). On the role of marketing theory. Journal of Marketing, 21. 413- 418. http://dx.doi.org/10.2307/1247264

Bhimani, A. (1993). Performance measures in UK manufacturing companies: The state of play. Management Accounting, London, 71(11), 20-30.

Brush, C. G., \& Chaganti, R. (1999). Business without Glamour? An analysis of Resources on Performance by Size and Age in Small Service and Retail Firms. Journal of Business Venturing, 14(3), 233-257. http://dx.doi.org/10.1016/S0883-9026(97)00103-1

Burton, A. (1994). Performance measurement: Responsibility accounting for current assets and liabilities. Management Accounting, London, 72(6), 51.

Carr, S., Mak, Y. T., \& Needham, J. E. (1997). Differences in strategy, quality management practices and performance reporting systems between ISO accredited and non-ISO accredited companies. Management Accounting Research, 8(4), 383-403. http://dx.doi.org/10.1006/mare.1996.0053

Cebeci, U., \& Beskese, A. (2002). An approach to the evaluation of quality performance of the companies in Turkey. Managerial Auditing Journal, 17(1), 92-100. http://dx.doi.org/10.1108/02686900210412306

Corbett C. J., Montes M. J., Kirsch D. A., \& Alvarez-Gil M. J. (2002). Does ISO 9000 certification pay?. ISO Management Systems, July-August, 31-39.

Demsetz, H. (1973). Industry Structure, Market Rivalry, and Public Policy. Journal of Law and Economics, 16 (April), 1-9. http://dx.doi.org/10.1086/466752

Dess, G. G., \& Davis, P. S. (1984). Porter's (1980) generic strategies as determinants of strategic group membership and organizational performance. Academy of Management Journal, 27(3), 467-488. 
http://dx.doi.org/10.2307/256040

Gupta, M. C. (1969). The effect of size, growth and industry on the financial structure of manufacturing companies. The Journal of Finance, 24(3), 517-529. http://dx.doi.org/10.2307/2325350

Haversjo, T. (2000). The financial effects of ISO 9000 registration for Danish companies. Managerial Auditing Journal, 15(1), 47-52. http://dx.doi.org/10.1108/02686900010304632

Hensen, G. S., \& Wernerfelt, B. (1989). Determinants of Firm Performance: The Relative Importance of Economic and Organizational Factors. Strategic Management Journal, 10(5), 399-411. http://dx.doi.org/10.1002/smj.4250100502

Heras, I., Casadesus, M., \& Dick, G. P. M. (2002). ISO 9000 certification and the bottom line: a comparative study of the profitability of Basque region companies. Managerial Auditing Journal, 17(1), 72-78. http://dx.doi.org/10.1108/02686900210412270

Jacobson, R., \& Aaker D. (1987). The Strategic Role of Product Quality. Journal of Marketing, 51(4), 31-44. http://dx.doi.org/10.2307/1251246

Johnson, R., \& Soenen, L. (2003). Indicators of successful companies. European Management Journal, 21(3), 364-369. http://dx.doi.org/10.1016/S0263-2373(03)00050-1

Kalleberg, A. L., \& Leicht, K. T. (1991). Gender and organizational performance: Determinants of small business survival and success. Academy of Management Journal, 34(1), 136-161. http://dx.doi.org/10.2307/256305

Kania, J. J., \& Mckean, J. R. (1978). An Industry Approach to Owner-Manager Control and Profit Performance. The Journal of Business, 51(2), 327 -343. http://dx.doi.org/10.1086/295999

Kay, J., \& Davis, E. (1990). What makes a company a chart topper?. Accountancy, August. 98-101.

Khan, M. R., \& Rocha, J. R. (1982). Recurring Managerial Problems in Small Business. American Journal of Small Business, 7(1), 50-59.

King, A., \& Lenox, M. (2001). Exploring the locus of profitable pollution reduction. Management Science, 48(2), 289-299. http://dx.doi.org/10.1287/mnsc.48.2.289.258

Krajewsky L. J., Ritzman L. P., \& Malhotra M. K (2010). Operations Management. (9th Ed.). USA: Prentice Hall.

Lee, J., Blevins, \& David, E. (1990). Profitability and Sales Growth in Industrialized versus Newly Industrializing Countries. Management International Review, 30(1), 87-101.

Mokhtar, M. Z., Karbhari, Y., \& Naser, K. (2005). Company Financial Performance and ISO 9000 registration: Evidence from Malaysia. Asia Pacific Business Review, 11(3), 349 - 367. http://dx.doi.org/10.1080/13602380500068441

Mokhtar, M. Z., Nik Mohd Kamil, N. F., \& Muda, M. S. (2006). Evaluation of Factors Affecting Corporate Performance of Malaysian Listed Companies. International Journal of Economics and Management, 1(1), 91 116.

Mulford, C. W. (1985). The Importance of a Market Value Measurement of Debt in Leverage Ratios: Replication and Extensions. Journal of Accounting Research, 23(2), 897-906. http://dx.doi.org/10.2307/2490847

Naser, K., Karbhari, Y., \& Mokhtar, M. Z. (2004). Impact of ISO 9000 registration on company performance. Managerial Auditing Journal, 19(4), 509-516. http://dx.doi.org/10.1108/02686900410530510

Naveh, E., \& Marcus, A. A. (2004). When does the ISO 9000 quality assurance standard lead to performance improvement? Assimilation and going beyond. IEEE Transactions on Engineering Management, 51(3), 352-362. http://dx.doi.org/10.1109/TEM.2004.830864

Pallant, J. (2001). SPSS Survival Manual. Open University Press, Maidenhead, Philadelphia.

Pat, L. (1995). Increasing shareholder value. Accountancy Ireland, Dublin, 27(2), 26-27.

Perkins, J., \& Van Zyl, A. (1994). Economic value added - Meeting management's mission. The Accountants' Journal, 73(1), 41-42. New Zealand.

Porter, M. E. (1979). The structure within industries and companies' performance. Review of Economics and Statistics, 61, 214 - 227. http://dx.doi.org/10.2307/1924589

Rupp, W. T., \& Smith, A. D. (2002). Study of the Dispersion Of CEO Compensation in the Metals Industry. 
American Business Review, 20(2), 57-66.

Schendel, D., \& Patton, G. R. (1978). A Simultaneous Equation Model of Corporate Strategy. Managerial Science, 27, 1611-1621.

Schmalensee, R. (1985). Do markets differ much? The American Economic Review, 75(3), 341-352.

Stevenson, W.J. (2009). Operations Management, 10/e. New York: McGraw- Hill Irwin.

Table 1. Descriptive statistics of the variables used

\begin{tabular}{|c|c|c|c|c|c|c|c|}
\hline & $\begin{array}{c}\text { N } \\
\text { Stat. }\end{array}$ & $\begin{array}{c}\text { Minimum } \\
\text { Statistic }\end{array}$ & $\begin{array}{c}\text { Maximum } \\
\text { Statistic }\end{array}$ & $\begin{array}{c}\text { Mean } \\
\text { Statistic }\end{array}$ & $\begin{array}{c}\text { Std. } \\
\text { Deviation }\end{array}$ & $\begin{array}{c}\text { Skewness } \\
\text { Statistic }\end{array}$ & $\begin{array}{c}\text { Kurtosis } \\
\text { Statistic }\end{array}$ \\
\hline ROE & 162 & -4.2546 & 1.0504 & $6.01146 \mathrm{E}-02$ & .438531 & -5.900 & 58.227 \\
\hline WC & 162 & .0031 & 5.9339 & 1.295752 & 1.134535 & 1.956 & 4.629 \\
\hline $\mathrm{CF}$ & 162 & -202916500 & 1670025000 & 60903627 & 208465969 & 5.536 & 35.335 \\
\hline TQ & 162 & -6.4118 & 15.7031 & .769926 & 1.666406 & 5.808 & 52.655 \\
\hline Size & 162 & 4358075 & 38670900000 & 1401574715 & 4028687121 & 6.504 & 50.855 \\
\hline Age & 162 & 4 & 94 & 28.44 & 17.94 & 1.484 & 2.913 \\
\hline Growth & 162 & -.52 & 11.90 & .1557 & 1.1059 & 8.291 & 82.071 \\
\hline \begin{tabular}{|l|} 
Capital \\
Structure \\
\end{tabular} & 162 & .0803 & 17.4579 & 1.032736 & 1.743826 & 6.737 & 55.423 \\
\hline \begin{tabular}{|l|} 
Industrial \\
Product
\end{tabular} & 162 & .00 & 1.00 & 0.3333 & 0.47287 & 0.714 & -1.509 \\
\hline $\begin{array}{l}\text { Consumer } \\
\text { Product }\end{array}$ & 162 & .00 & 1.00 & 0.0926 & 0.29076 & 2.837 & 6.126 \\
\hline Construction & 162 & .00 & 1.00 & 0.1111 & 0.31524 & 2.498 & 4.293 \\
\hline Property & 162 & .00 & 1.00 & 0.1111 & 0.31524 & 2.498 & 4.293 \\
\hline $\begin{array}{l}\text { Trading \& } \\
\text { Services }\end{array}$ & 162 & .00 & 1.00 & 0.1852 & 0.38965 & 1.636 & 0.685 \\
\hline Plantation & \begin{tabular}{|l|}
162 \\
\end{tabular} & .00 & 1.00 & 0.0556 & 0.22977 & 3.917 & 13.509 \\
\hline Others & 162 & .00 & 1.00 & 0.0988 & 0.29927 & 2.715 & 5.438 \\
\hline
\end{tabular}


Table 2. T-Test Results on the ISO 9000 and Non-ISO 9000 Registered Companies

\begin{tabular}{|c|c|c|c|c|c|}
\hline & ISO & Mean & Std. Deviation & t-test & Sig. (2-tailed) \\
\hline \multirow[t]{2}{*}{ ROA } & 0 & -.123418 & .183998 & -6.757 & $0.000 *$ \\
\hline & 1 & $3.81941 \mathrm{E}-02$ & .111741 & & \\
\hline \multirow[t]{2}{*}{ ROE } & 0 & $3.56667 \mathrm{E}-02$ & .605418 & -0.708 & 0.48 \\
\hline & 1 & $8.45625 \mathrm{E}-02$ & .138854 & & \\
\hline \multirow[t]{2}{*}{ ROS } & 0 & -.657358 & 1.062078 & -6.246 & $0.000^{*}$ \\
\hline & 1 & .105979 & .285667 & & \\
\hline \multirow[t]{2}{*}{$\mathrm{WC}$} & 0 & .930886 & 1.118001 & -4.311 & $0.000^{*}$ \\
\hline & 1 & 1.660619 & 1.034853 & & \\
\hline \multirow[t]{2}{*}{ LS } & 0 & .352672 & .899258 & -0.332 & 0.740 \\
\hline & 1 & .397469 & .815927 & & \\
\hline \multirow[t]{2}{*}{$\mathrm{CF}$} & 0 & 35828117.1951 & 107230429.0253 & -1.537 & 0.126 \\
\hline & 1 & 85979138.1698 & 273290504.7727 & & \\
\hline \multirow[t]{2}{*}{ EVA } & 0 & 96732938.6346 & -169460736.7929 & -5.236 & $0.000^{*}$ \\
\hline & 1 & 43466019.1864 & 171310631.5362 & & \\
\hline \multirow{2}{*}{ Tobin's Q } & 0 & -.234401 & 2.171219 & -0.189 & 0.850 \\
\hline & 1 & .551679 & 1.174936 & & \\
\hline \multirow[t]{2}{*}{ Age } & 0 & 31.38 & 21.89 & 2.106 & $0.037 *$ \\
\hline & 1 & 25.51 & 12.29 & & \\
\hline \multirow[t]{2}{*}{ Size } & 0 & 7698656.30 & 1627132223.00 & -2.015 & $0.046^{*}$ \\
\hline & 1 & 2033283804.94 & 5404430627.88 & & \\
\hline \multirow[t]{2}{*}{ Growth } & 0 & 0.0055 & 0.7063 & -1.739 & 0.084 \\
\hline & 1 & 0.3059 & 1.3845 & & \\
\hline Capital & 0 & 1.4352 & 2.09508 & 3.011 & $0.003 *$ \\
\hline Structure & 1 & 0.63019 & 1.1842 & & \\
\hline Industrial & 0 & .2593 & .44096 & -2.013 & $0.046^{*}$ \\
\hline Product & 1 & .4074 & .49441 & & \\
\hline Consumer & 0 & .0617 & .24216 & -1.355 & 0.177 \\
\hline Product & 1 & .1235 & .33101 & & \\
\hline \multirow[t]{2}{*}{ Construction } & 0 & .0741 & .26352 & -1.501 & 0.135 \\
\hline & 1 & .1481 & .35746 & & \\
\hline \multirow[t]{2}{*}{ Property } & 0 & .1235 & .33101 & 0.497 & 0.620 \\
\hline & 1 & .0988 & .30021 & & \\
\hline Trading \& & 0 & .2099 & .40976 & 0.806 & 0.422 \\
\hline Services & 1 & .1605 & .36935 & & \\
\hline \multirow[t]{2}{*}{ Plantation } & 0 & .0617 & .24216 & 0.341 & 0.734 \\
\hline & 1 & .0494 & .21802 & & \\
\hline Other & 0 & .1975 & .40062 & 4.438 & $0.000^{*}$ \\
\hline Industries & 1 & .0000 & .00000 & & \\
\hline
\end{tabular}

Indicator for ISO: 0 - Non ISO Companies; 1 - ISO Companies

* $\quad 10 \%$ significance

** $5 \%$ significance

*** $\quad 1 \%$ significance 